\title{
Application of technical measures to improve the work safety - systemic guidelines
}

\author{
Adam Górny ${ }^{1, *}$ \\ ${ }^{1}$ Poznań University of Technology, Faculty of Engineering Management, Institute of Safety and \\ Quality Engineering, ul. Prof. Rychlewskiego 2 (room 357), 60-965 Poznań, Poland
}

\begin{abstract}
In order to improve working conditions in conformity with the ISO 45001 standard, organizations need to address a wide range of issues that are essential for compliance with system requirements. One of them is to limit technical measures to those that are necessary for task completion and have been designed to mitigate threats and strains. To avert potential hazards, it is imperative to deploy improvement measures that are adequate for the nature of non-conformities and will either eliminate or reduce the underlying causes of irregularities. By employing solutions in keeping with the ISO 45001 standard, organizations can streamline the selection and rollout of their solutions to ensure effective systemic management across a range of areas from planning to implementation support, operations, outcome assessments to the identification of follow-up improvements. The measures will limit threat incidence and ultimately help improve performance.
\end{abstract}

\section{Introduction}

In order to ensure that a working environment is compatible with production, organizations are compelled constantly to search for and apply solutions that adequately reflect their changing needs. This applies in particular to technical and organizational arrangements that enhance the effectiveness of existing designs. Technical guidelines for designing the working environment are a priority category of requirements that are vital for ensuring safe working conditions. In the hierarchy of improvement measures, technical measures hold a privileged position due to their effectiveness in eliminating and/or mitigating threat impacts.

The use of technical solutions should be viewed as one of the prime responsibilities of employers and recognized as a priority consideration in selecting and deploying solutions designed to reduce risks associated with an employer's business. This is typically achieved by ensuring that all machinery and equipment installed at a particular workstation meets safety requirements and can be used safely and hygienically by workers [1-4]. Such solutions will avert the adverse impacts of threats and mitigate threat-related risks, ultimately reducing the related losses $[3,5]$.

For measures, and in particular those that follow systemic guidelines, to be effective, a specific course of action must be taken [6]. One must not rely on technical solutions alone to secure the desired improvements. Equally essential are organizational measures that

\footnotetext{
${ }^{*}$ Corresponding author: adam.gorny@put.poznan.pl
} 
determine the effectiveness of technical solutions. Improvements also require solutions that will prove to be effective in specific areas of non-conformity.

Occupational safety has afforded a new perspective on the aforementioned issues, adding new areas of focus that are critical for achieving the desired outcomes [7-9]. Incompliance with technical requirements is seen as a major risk factor and an impediment to ensuring safe working conditions $[3,10]$.

\section{Scope of requirements}

To secure the safe operation of technical equipment, all threats with a potential to trigger negative impacts should be eliminated. Such threats include unimpeded access to unsecured machine parts and the lack of effective safety measures that cannot be easily bypassed. It is equally important to ensure operation and maintenance with no negative impacts on workers $[11,12]$. This may involve access to signaling and control systems. In assessing losses, the entire cost of potential accidents should be considered. That cost accounts for a significant proportion of the overall cost involved in the use of machines in manufacturing $[4,5,13,14]$.

To satisfy requirements, businesses need to make sure that all of their machinery and equipment comply with guidelines that ensure their safe operation. A basic prerequisite for operational safety is design-stage verification [12]. During the design process, utmost care must be taken to eliminate hazards, reduce risks and apply protective measures that are adequate for current operations [11]. Threat reduction is conditional upon the use of design solutions that either fully eliminate threat causes or reduce threat impacts. To achieve the desired safety level, it is vital to follow EN ISO 12100 [12] guidelines as well as standards harmonized with the European legal system [13]. Compliance with such requirements is verified on the basis of risk assessment outcomes. In selecting solutions, companies should consider occupational risk assessment outcomes related to the work they perform and the technical risks associated with the solutions in place.

A systemic assessment of requirements should rest on the premise that the solution in place should ensure lasting success in the functioning of the concerned organization. This is especially true for organizations whose assessment of the capability to conduct and improve operations is intended to rely on ISO 45001 guidelines [15]. The solution's compliance with the requirements and the provision of appropriate operating conditions should be considered essential for creating an environment in which prerequisites for the use of technical equipment will be developed systemically.

In order to secure the technical resources required to maintain the system and achieve the desired outcomes, organizations need to ensure that the technical equipment they use complies with systemic management guidelines [15]. The technical solutions in place must be well aligned with the strategic goals of the organization to ensure the effective performance of processes and a safe, healthy and worker-friendly working environment. To obtain the intended benefits, machinery and equipment should be operated in keeping with guidelines that require:

- Improvements that adequately reflect the nature of any identified non-conformities and the existing conditions,

- Due consideration of all instances of inappropriate use of technical equipment in the process of identifying improvement potential,

- The identification of root causes of potential adverse events rather than limiting oneself to identifying immediate causes only; to that end, organizations should select and deploy solutions that will effectively prevent any future non-conformities,

- The use of technical equipment that will significantly contribute to improving operational performance and satisfying relevant requirements. 
The use of new technologies can also be viewed as instrumental in bolstering the effectiveness of systemic management and additionally contributing to the efficiency of task performance $[9,14]$.

To successfully conduct operational activities, a significant part of which entails the use of technical machinery and equipment, it is critical to [15]:

- Recognize the vital role of choosing correct technical equipment for ensuring the proper performance of tasks,

- Employ solutions that will help eliminate threats and/or reduce risks by technical means,

- Actively respond to failures and other disruptions in the proper functioning of technical equipment,

- Ensure the proper operation and use of equipment by employing competent workers capable of using equipment in changing conditions.

Such measures must fit into a risk reduction strategy aimed at building up the ability to use equipment under significant stress. Once the selected measures have been verified for compliance with systemic guidelines, they can be rolled out in particular areas of systemic management. The key technical measures derived from systemic requirements are summarized in Table 1.

Table 1. Technical measures derived from systemic requirements

\begin{tabular}{|c|l|}
\hline $\begin{array}{c}\text { Systemic } \\
\text { requirement area }\end{array}$ & \multicolumn{1}{c|}{ Technical measure } \\
\hline \multirow{5}{*}{ Planning } & $\begin{array}{l}\text { Plans to deploy technical measures should account for: } \\
\text { - the nature of existing non-conformities and specifically the level of risk } \\
\text { they pose, } \\
\text { - the impact of such non-conformities on the ability to perform production tasks, } \\
\text { - the prescribed/required effectiveness in preventing threats and strenuousness, } \\
\text { - design guidelines for the adaptation of technical equipment to worker } \\
\text { needs and capabilities, } \\
\text { - the requirements laid down in applicable laws, } \\
\text { - compliance with any adopted principles (occupational health and safety } \\
\text { policies) and the ability to use occupational safety measures to the desired } \\
\text { effect. }\end{array}$ \\
\hline \multirow{5}{*}{ Support } & $\begin{array}{l}\text { Support for the systemic measures extends to: } \\
\text { - ensuring an adequate level of skills among workers assigned to use } \\
\text { technical equipment, } \\
\text { - ensuring the availability of properly formulated, approved and useful } \\
\text { manuals (documentation), } \\
\text { - keeping a record of all efforts aimed at ensuring the proper use of } \\
\text { technical equipment. }\end{array}$ \\
\hline \multirow{2}{*}{$\begin{array}{c}\text { Outcome } \\
\text { assessment }\end{array}$} & $\begin{array}{l}\text { Operational measures include: } \\
\text { - ensuring the proper handling of any equipment that is considered a threat } \\
\text { or that is likely to precipitate emergencies, } \\
\text { - defining conditions and guidelines for the use of technical equipment and } \\
\text { rules for outcome verification, } \\
\text { - deploying technical measures for risk reduction, } \\
\text { - following guidelines to mitigate threats and specifically to modify high- } \\
\text { risk processes. }\end{array}$ \\
\hline $\begin{array}{l}\text { Measure outcome assessment includes: } \\
\text { - identifying performance-related non-conformities with any adopted } \\
\text { principles and rules, } \\
\text { - an assessment of current status and a determination of improvement potential. }\end{array}$ \\
$\begin{array}{l}\text { Improvement includes: } \\
\text { - identifying the need for changes in the use of technical equipment, } \\
\text { - an assessment of the effectiveness of improvement measures. }\end{array}$ \\
\hline
\end{tabular}


Any systemic technical measures must be duly structured and involve the management, workers and persons participating in their implementation.

Measures must be documented and assessed on an ongoing basis to ensure that solutions are continuously updated and comply with changing requirements.

\section{The nature of efforts to satisfy requirements}

To complete tasks involving technical equipment, organizations need to assess their ability to replace humans with such equipment, deploy automation and robotization systems, put in place protection measures and adopt organizational, procedural and administrative solutions [11]. It is vital that the technical equipment to which workers are directly exposed does not generate excessive workloads. Commonly, due to the complexity of irregularities and the need to identify them and propose solutions that reduce their adverse impacts on humans in danger zones, it is necessary to assess $[12,14]$ :

- The functions of technical equipment, including the extent to which such equipment meets technological needs in production,

- The operational reliability of equipment,

- The level of difficulty involved in operating and maintaining equipment,

- The level of difficulty involved in repairing and overhauling equipment.

To ensure that the solutions selected by organizations are effective, adequate and improvable, they must lend themselves to assessment designed to identify such potential issues in existing processes as may result in the production of defective products. Any measures identified during such an assessment may be verified against the needs and expectations of company stakeholders to ensure they obtain their desired benefits.

The most common areas of non-conformity, as identified in enterprises that were formulating safety requirements and putting in place manufacturing systems that relied on systemic guidelines, are presented in Figure 1. Eight medium-sized enterprises representing a range of industries that declared they employed systemic guidelines to oversee occupational safety, were examined. The conclusions were reached on the basis of the findings of internal audits conducted to assess the proper functioning of OHS management systems with a view to ensuring that production tasks could be completed without adverse impacts on workers.

The assessment covers measures suggested by systemic guidelines that affected the functioning of technical equipment (see: Table 1).

Specific potential non-conformities were identified with reference to:

\section{CAUSE ---> IRREGULARITY ---> EFECT/CONSEQUENCE}

with specific adverse impacts ascribed to them [14]. The assessment covered any adverse impacts on exposed people, any direct adverse impacts on technical equipment and any indirect impacts on the working environment.

The observed impacts may result from failures to adapt technical equipment to taskrelated needs, errors during operation and improper operation of equipment leading to failures and damage.

Threat-prevention guidelines demonstrate that to effectively correct irregularities, organizations should target their interference at the root causes of issues $[1,5,12]$. Common issues resulting from key non-conformities are summarized in Table 2. 


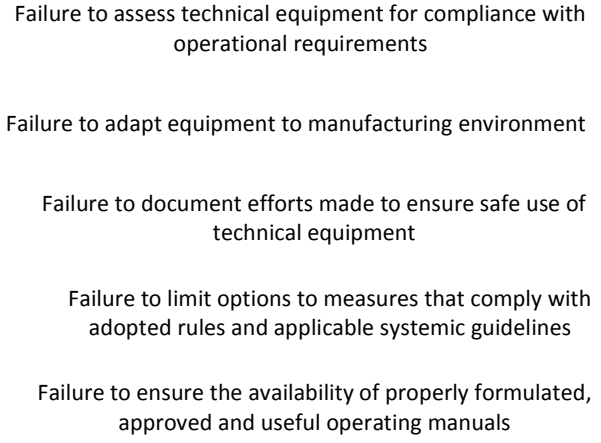

Failure to assess technical equipment for compliance with operational requirements

Failure to adapt equipment to manufacturing environment

Failure to document efforts made to ensure safe use of technical equipment

Failure to limit options to measures that comply with adopted rules and applicable systemic guidelines

Failure to ensure the availability of properly formulated, approved and useful operating manuals

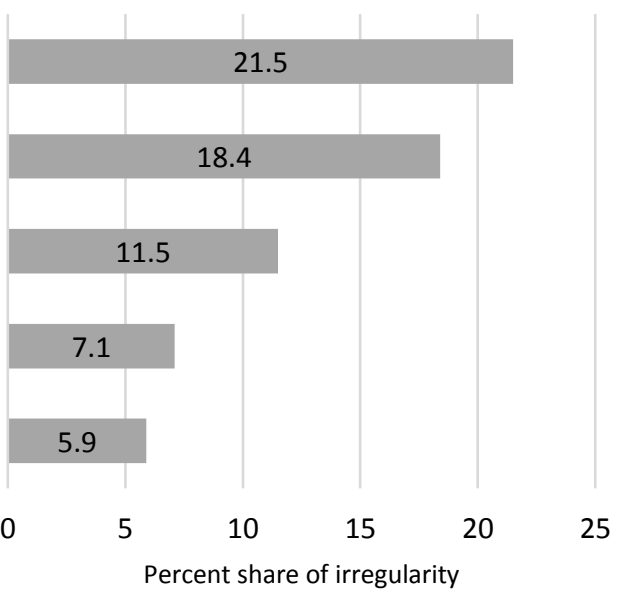

Fig. 1. Percentage of key identified non-conformities affecting the operation of machinery and equipment.

Table 2. Irregularities, their causes and consequences examined with a view to selecting adequate improvement measures

\begin{tabular}{|l|l|l|}
\hline \multicolumn{1}{|c|}{$\begin{array}{c}\text { Cause } \\
\text { (of non-conformity) }\end{array}$} & \multicolumn{1}{c|}{$\begin{array}{c}\text { Fault } \\
\text { (nature of irregularity) }\end{array}$} & \multicolumn{1}{c|}{$\begin{array}{c}\text { Effect } \\
\text { (impact of issue) }\end{array}$} \\
\hline $\begin{array}{l}\text { Failure to assess technical } \\
\text { equipment for compliance } \\
\text { with operational requirements }\end{array}$ & $\begin{array}{l}\text { Organization unaware of its } \\
\text { status of compliance with } \\
\text { requirements } \\
\text { Organization unaware of the } \\
\text { need to carry out repairs and } \\
\text { overhauls }\end{array}$ & $\begin{array}{l}\text { The technical condition of } \\
\text { equipment causes accidents } \\
\text { and disrupts processes }\end{array}$ \\
\hline $\begin{array}{l}\text { Failure to adapt equipment to } \\
\text { manufacturing environment } \\
\text { operations from prescribed } \\
\text { operating parameters }\end{array}$ & $\begin{array}{l}\text { Equipment / processes } \\
\text { adversely impacting workers } \\
\text { and causing excessive wear } \\
\text { and tear of equipment }\end{array}$ \\
\hline $\begin{array}{l}\text { Failure to document efforts } \\
\text { made to ensure safe use of } \\
\text { technical equipment }\end{array}$ & $\begin{array}{l}\text { Failure to supervise scope of } \\
\text { work }\end{array}$ & $\begin{array}{l}\text { Organization uses equipment } \\
\text { that fails to ensure required } \\
\text { safety and whose } \\
\text { specifications differ from } \\
\text { those intended or required. }\end{array}$ \\
\hline $\begin{array}{l}\text { Failure to limit options to } \\
\text { measures that comply with } \\
\text { adopted rules and applicable } \\
\text { systemic guidelines }\end{array}$ & $\begin{array}{l}\text { Equipment used despite the } \\
\text { absence of proper operating } \\
\text { principles }\end{array}$ & $\begin{array}{l}\text { Use of equipment leading to } \\
\text { excessive impact on workers } \\
\text { and the technical condition of } \\
\text { equipment }\end{array}$ \\
\hline $\begin{array}{l}\text { Failure to ensure the } \\
\text { availability of properly } \\
\text { formulated, approved and } \\
\text { useful operating manuals }\end{array}$ & $\begin{array}{l}\text { Lack of manuals stipulating } \\
\text { rules of equipment operation }\end{array}$ & $\begin{array}{l}\text { Inappropriate operation of } \\
\text { technical equipment leading } \\
\text { to accidents and equipment } \\
\text { damage }\end{array}$ \\
\hline
\end{tabular}

Awareness of potential impacts may inspire efforts to eliminate the causes of nonconformities and reduce the likelihood of occurrence and/or severity of adverse events [14]. It is essential that solutions do not impose unacceptable loads on workers. Organizations 
should employ normative solutions that are relevant to the issues at hand and/or to the technical equipment affected thereby.

\section{Conclusions}

The use of system requirements to ensure occupational safety helps improve organizations' ability to perform their tasks. This is achieved by following design guidelines and employing technical measures as well as, ideally, by establishing an environment that is conducive to the proper use of technical equipment.

The potentially adverse effects that an organization seeks to eliminate should be identified with reference to the working environment, the characteristics of technical equipment and the impacts of non-conformities on workers. All identified non-conformities may contribute to failures to comply with systemic requirements derived from ISO 45001.

By selecting the right technical equipment and improving conditions for its use, organizations achieve compliance with system requirements. To this end, they need to account for the specifics of their processes. Their measures should eliminate the causes of non-conformities and help adequately address any discovered impacts. Their solutions should recognize workers as activity agents. To ensure they function properly, organizations should respect the hierarchy of improvement measures enshrined in normative guidelines. To make certain that their measures are consistent with proven guidelines, organizations should employ solutions that comply with normative requirements.

Their measures must extend to all areas that are of relevance for safe operation. The aim is to ensure the availability of technical equipment that is user-friendly and compliant with systemic guidelines, i.e. enable the implementation of measures derived from basic guidelines for the systemic management of working conditions. This will help limit the impact of threats on potential stakeholders, who are viewed as the target group for risk mitigation. Technical requirements should apply to all projects and all stages of rollout, execution and improvement, as prescribed in systemic guidelines.

\section{Acknowledgement}

This paper has been prepared as a part of Research Topic No. 0811/SBAD/1028 entitled: "Aspects of employing contemporary technologies for organization risk management".

\section{References}

1. A. Górny, Procedia Manufacturing, 3, 4700-4707 (2015).

2. G.R. Narasimhan, Y. Peng, T. Crowe, L. Hagel, J. Dosman, W. Pickett, Accident Analysis \& Prevention, 42(4), 1226-1231 (2010).

3. Y. Li, F.W. Guldenmund, Safety Science, 103, 94-123 (2018).

4. F. Gauthier, Y.A. Chinniah, G. Abdul-Nour, S. Jocelyn, B. Aucourt, G. Bordeleau, A. Ben Mosbah, Safety Science, 133, 105011 (2021).

5. P.P. Philip, Security and Loss Prevention (Elsevier, 2019).

6. Ch. Uhrenholdt Madsen, M.L. Kirkegaard, J. Dyreborg, P. Hasle, Safety Science, 129, 104843 (2020).

7. D. Palačić, Safety Engineering, 9(1), 13-21 (2019).

8. P.N. Neag, L. Ivascu, A. Draghici, MATEC Web of Conferences, 305(2), 00002 (2020).

9. M.J. Djapan, I.D. Mačužić, D.P. Tadić, G. Baldissone, Safety Science, 119, 280-291 (2019).

10. T. Karkoszka, Procedia Manufacturing, 13, 1463-1469 (2017). 
11. Directive 2006/42/EC of the European Parliament and of the Council of 17 May 2006 on machinery, and amending Directive 95/16/EC (recast); OJ L 157, 9.6.2006, p. 24-86, as amended.

12. EN ISO 12100 (PN-EN ISO 12100:2012), Safety of machinery. General principles for design. Risk assessment and risk reduction (2010).

13. Y.A. Chinniah, B. Aucourt, R. Bourbonnière, Safety Science, 93, 152-161 (2017).

14. A. Górny A., IOP Conference Series: Materials Science and Engineering, 564, 012091 (2019).

15. ISO 45001 (PN-ISO 45001: 2018-06), Occupational health and safety management systems. Requirements with guidance for use (2018). 